\title{
Impact of Integrated Nutrient Management on Yield and Quality Parameters of Strawberry (Fragaria $\times$ ananassa Duch.) Cv. "Sabrina" under Polyhouse
}

\author{
Esmatullah Ahmadi", M.K. Honnabyraiah, Ashok S. Alur, \\ J. Dinakara Adiga and Venkat Rao
}

\author{
Department of Fruit Science, College of Horticulture, UHS Campus, \\ GKVK Post, Bengaluru, Karnataka-560 065, India \\ *Corresponding author
}

\section{A B S T R A C T}

\begin{tabular}{|l|}
\hline K e y w o r d s \\
Strawberry, \\
Nutrient, Yield, \\
Quality, Sabrina. \\
\hline Article Info \\
\hline $\begin{array}{l}\text { Accepted: } \\
\text { 10 July 2017 } \\
\text { Available Online: } \\
\text { 10 September } 2017\end{array}$ \\
\hline
\end{tabular}

Keywords

Strawberry, Nutrient, Yield, Quality, Sabrina.

\section{Introduction}

Strawberry (Fragaria $\times$ ananassa Duch.) is a high value and low volume crop belonging to the family Rosaceae. The cultivated varieties are octaploid $(2 n=56)$ in nature and has been derived from North American species, Fragaria chiloensis and Fragaria verginiana in France in the $17^{\text {th }}$ century. Strawberry can be grown under varied climatic conditions while it is mainly a crop of the temperate climate which can be grown in sub-tropical climate and even at high altitudes of tropical climate. Presently, strawberry is being cultivated in about 75 countries. The major strawberry growing countries are China, United States, Canada, France, Italy, United Kingdom, Bulgaria, Poland, Southern and
Eastern Africa, New Zealand, Australia and Japan. In India Maharashtra is the leading state in India both in area and production followed by Haryana, Punjab, Uttar Pradesh, Jammu and Kashmir, Uttrakhand and lower hills of Himachal Pradesh with a total area of 0.21 thousand ha and production of 1.61 thousand MT(Anon. 2014).

Nutritionally, strawberry is a low calorie carbohydrate fruit but a rich source of vit. A (60 IU/100g of edible portion), vit. C (30$120 \mathrm{mg} / 100 \mathrm{~g}$ of edible portion), fiber and also has high pectin content $(0.55 \%)$ available in the form of calcium pectate. Water is a major constituent $(90 \%)$ of strawberry fruit. Ellagic 
acid is a naturally occurring plant phenol. It has been found to inhibit the cancer disease and asthma by the regular consumption of its fruits (Wange and Kzlogoz, 1998).Among the various factors which contribute towards the growth, yield and quality of strawberry, nutrition is the most important and it has direct effect on bearing and production (Umar et al., 2009).It is well reported that the extensive use of chemical fertilizers adversely affect the soil health and results in decreased crop productivity and quality (Macit et al., 2007).Hence, considering the economy, environment friendliness and maintenance of better soil health, it is imperative that plant nutrients are to be used effectively by adopting the integrated nutrient management practices. The basic principle behind this concept is to supply both the chemical fertilizers and organic manures a long with bio-fertilizers for a sustainable crop production in most efficient manner. The beneficial effects of combined application of chemical fertilizers with organic manures viz., farm yard manure, vermicompost, bio fertilizers and many more of such materials are universally known. A balanced application of both organic and inorganic fertilizers with bio fertilizers appears to be an ideal proposition to meet nutrient requirements for most of the horticultural crops. Adoption of integrated nutrient management practices in strawberry is more essential to realize higher yield, quality and returns. Hence investigations were carried out to develop nutrient management for strawberry cultivar Sabrina subjected to various treatment combinations of organic, inorganic and bio-fertilizer.

\section{Material and Methods}

Field experiment on strawberry was conducted under polyhouse condition at College of Horticulture, Bengaluru, Karnataka, India during 2016-2017. The soil of the experimental site was medium sandy loam soil. The forest soil having good physical and chemical properties with the $\mathrm{pH}$ of 5.79wasmixed with native soil in polyhouse in order to increase the fertility. The uniform tissue culture planting materials were procured from Kf bioplants, Pune, Maharastra. This experiment was undertaken to find out the best nutrient sources to obtain good growth, yield and yield attributes in strawberry. The experiment was laid out in Randomized Block Design with nine treatments replicated three times having plot size $1.0 \times 2.0 \mathrm{~m}^{2}$ accommodating twelve plants in each plot at a spacing of $30 \mathrm{~cm} \times 60$ $\mathrm{cm}$. The nine treatments consisted of $_{1}-$ Control (100\% RDF), $\mathrm{T}_{2}-100 \% \mathrm{RDF}+$ VAM @ $10 \mathrm{~kg} / \mathrm{ha}+0.4 \%$ Boron spray, $\mathrm{T}_{3}-$ $100 \% \mathrm{RDF}+\mathrm{VAM} @ 10 \mathrm{~kg} / \mathrm{ha}+0.5 \%$ $\mathrm{ZnSO}_{4}$ spray, $\mathrm{T}_{4}-100 \% \mathrm{RDF}+\mathrm{VAM} @ 10$ $\mathrm{kg} / \mathrm{ha}+0.4 \%$ Boron spray $+0.5 \% \mathrm{ZnSO}_{4}$ spray, $\mathrm{T}_{5}-75 \% \mathrm{RDF}+\mathrm{VAM} @ 15 \mathrm{~kg} / \mathrm{ha}+$ $0.4 \%$ Boron spray, $\mathrm{T}_{6}-75 \% \mathrm{RDF}+\mathrm{VAM}$ @ $15 \mathrm{~kg} / \mathrm{ha}+0.5 \% \mathrm{ZnSO}_{4}$ spray, $\mathrm{T}_{7}-75 \%$ $\mathrm{RDF}+\mathrm{VAM} @ 15 \mathrm{~kg} / \mathrm{ha}+0.4 \%$ Boron spray $+0.5 \% \mathrm{ZnSO}_{4}$ spray, $\mathrm{T}_{8}-100 \%$ NPK through $\mathrm{FYM}$ and 9 $^{-} 75 \% \mathrm{RDF}+25 \%$ NPK through vermicompost. To determine the fruit yield per plant, total number of fruits per plant was multiplied with average fruit weight produced per plant and expressed as fruit yield per plant in grams. To determine the fruit yield per ha, the total amount of fruits produced from the plants was multiplied with total number of plants per hectare and expressed in tons per hectare. The TSS was estimated with the help of a digital refractometer $\left(0-32^{0} \mathrm{~B}\right)$ by putting a few drops of juice on the prism. The total sugars were estimated by the method outlined by Lane and Eynon and described by Ranganna (1986) with some modifications.

\section{Results and Discussion}

\section{Yield parameters}

The results on number of fruits per plant showed significant difference among the 
different treatments, The maximum number of fruits per plant (19.07) was recorded in the plants supplied with100\% RDF + VAM @ 10 $\mathrm{kg} / \mathrm{ha}+0.4 \%$ Boron spray $+0.5 \% \mathrm{ZnSO}_{4}$ spray $\left(\mathrm{T}_{4}\right)$. The minimum number of fruits per plant was observed in $100 \%$ NPK through FYM $\left(\mathrm{T}_{8}\right)$. The increase in number of fruits per plant with the application of $100 \%$ RDF + VAM @ $10 \mathrm{~kg} / \mathrm{ha}+0.4 \%$ Boron spray + 0.5\% $\mathrm{ZnSO}_{4}$ spray $\left(\mathrm{T}_{4}\right)$ might be due to increased phosphorus availability through application of soluble phosphatic fertilizers and interaction of arbuscular mycorrhizae with the inorganic phosphatic fertilizers when applied to the soil to reach the optimum productivity. This interaction depends both on the infectivity and efficiency of AM species and sorption characteristics of the soil which affect the concentration of nutrients in the soil solution which may have increased various endogenous hormonal levels in plant tissue which might be responsible for enhanced pollen germination and pollen tube formation which might have ultimately increased fruit set and number of fruits per plant.

These results are in accordance with the earlier findings of Singh et al., (2015), Yadav et al., (2010), Khalid et al., (2013) in strawberry, The minimum number of fruits per plant (12.80) were recorded in $\mathrm{T}_{9}-75 \%$ $\mathrm{RDF}+25 \% \mathrm{NPK}$ through vermicompost and $100 \%$ NPK through FYM $\left(\mathrm{T}_{8}\right)$ respectively.

The results on fruit length, fruit diameter, fruit volume and fruit weight showed significant difference among the different treatments. The maximum fruit length, fruit weight, fruit diameter and fruit volume $(4.28 \mathrm{~cm}, 16.23 \mathrm{~g}$, $4.13 \mathrm{~cm}$ and $18.83 \mathrm{~mL}$ respectively) were recorded in the plants supplied with $100 \%$ $\mathrm{RDF}+\mathrm{VAM} @ 10 \mathrm{~kg} / \mathrm{ha}+0.4 \%$ Boron spray $+0.5 \% \mathrm{ZnSO}_{4}$ spray $\left(\mathrm{T}_{4}\right)$ and these were on par with the application of $100 \% \mathrm{RDF}+$ VAM @ $10 \mathrm{~kg} / \mathrm{ha}+0.4 \%$ Boron spray (4.09 $\mathrm{cm}$ and $15.61 \mathrm{~g}$ respectively) $\mathrm{T}_{2}$. The increased fruit length, fruit diameter and fruit weight attributed to better fillings of fruits may be due to more balanced uptake of nutrients which may have led to better metabolic activities in the plant which ultimately led to high protein and carbohydrate synthesis. Besides, nitrogen filling abilities of the microbial inoculants, the capacity to releasing phytohormones especially, gibberellins should be released which increases the fruit size (Ahmad and Mohammad, 2012). The applied N, P, K and biofertilizer were utilized efficiently by the plant, which resulted in producing maximum photosynthates in terms of high biomass and translocation of assimilates to the developing sink results in higher fruit weight (Patil and Shinde, 2013). Similar observations have been reported by Yadav et al., (2010), Khalid et al., (2013and Martinsson et al., (2009) in strawberry (Table 1).

The yield per plant varied significantly among the treatments. The plants which received $100 \%$ RDF + VAM @ 10kg/ha + 0.4\% Boron spray $+0.5 \% \quad \mathrm{ZnSO}_{4}$ spray $\left(\mathrm{T}_{4}\right)$ recorded maximum yield per plant $(309.70 \mathrm{~g})$ and yield per hectare $(17.20 \mathrm{t} / \mathrm{ha})$. The minimum yield per plant (129.59 g) and yield per hectare (7.20 t/ha) was recorded in the plants which received $100 \%$ NPK through FYM $\left(\mathrm{T}_{8}\right)$. The increased fruit set percentage and number of fruits per plant ultimately resulted in increased yield (Table 2). The yield attributes or the sink capacity of a crop is determined by its vegetative growth throughout the life cycle of the plant. Vigorous growth is associated with higher sink capacity of a crop. The increase in yield can be resulted from better root proliferation. In addition, increased nutrient elements in the soil which enhanced the uptake of nutrients and water caused to higher photosynthesis leading to an increase in assimilation rates (Lieten, 1996). These results are in accordance with the findings of Ahmad and Mohammad (2012), Macit et al., (2007), Zargar et al., (2008), and Erturk et al., (2012) in strawberry. 
Table.1 Effect of integrated nutrient management (INM) on fruit parameters of Strawberry cv. Sabrina

\begin{tabular}{|c|c|c|c|c|}
\hline Treatments & $\begin{array}{c}\text { Fruit } \\
\text { weight }(\mathrm{g})\end{array}$ & $\begin{array}{l}\text { Fruit length } \\
\text { (cm) }\end{array}$ & $\begin{array}{c}\text { Fruit } \\
\text { diameter }(\mathrm{cm})\end{array}$ & $\begin{array}{c}\text { Fruit volume } \\
(\mathrm{mL})\end{array}$ \\
\hline $\mathrm{T}_{1}-$ & 14.90 & 3.73 & 3.35 & 17.53 \\
\hline $\mathrm{T}_{2}-$ & 15.61 & 4.09 & 3.77 & 18.03 \\
\hline$T_{3}-$ & 15.33 & 3.85 & 3.60 & 17.77 \\
\hline $\mathrm{T}_{4}-$ & 16.23 & 4.28 & 4.13 & 18.83 \\
\hline $\mathrm{T}_{5}-$ & 14.17 & 3.36 & 3.09 & 16.77 \\
\hline $\mathrm{T}_{6}-$ & 13.92 & 3.29 & 2.96 & 16.37 \\
\hline $\mathrm{T}_{7}-$ & 14.63 & 3.47 & 3.19 & 17.17 \\
\hline $\mathrm{T}_{8}-$ & 10.14 & 2.63 & 2.45 & 15.38 \\
\hline $\mathrm{T}_{9^{-}}$ & 13.57 & 2.75 & 2.73 & 16.07 \\
\hline S.Em \pm & 0.43 & 0.25 & 0.13 & 0.47 \\
\hline CD @ 5\% & 1.29 & 0.75 & 0.4 & 1.40 \\
\hline
\end{tabular}

Table.2 Effect of integrated nutrient management (INM) on yield and yield parameters of Strawberry cv. Sabrina

\begin{tabular}{|l|c|c|c|c|}
\hline \multicolumn{1}{|c|}{ Treatments } & $\begin{array}{c}\text { Number of } \\
\text { fruits per plant }\end{array}$ & $\begin{array}{c}\text { Yield per } \\
\text { plant (g) }\end{array}$ & $\begin{array}{c}\text { Yield per } \\
\text { hectare (tones) }\end{array}$ & B:C (ratio) \\
\hline $\mathrm{T}_{1-}-$ & 15.67 & 233.41 & 12.96 & $1: 1.57$ \\
\hline \hline $\mathrm{T}_{2}-$ & 17.13 & 267.50 & 14.86 & $1: 1.92$ \\
\hline \hline $\mathrm{T}_{3}-$ & 16.33 & 250.17 & 13.89 & $1: 1.74$ \\
\hline $\mathrm{T}_{4}-$ & 19.07 & 309.70 & 17.20 & $1: 2.37$ \\
\hline \hline $\mathrm{T}_{5}-$ & 14.33 & 203.00 & 11.14 & $1: 1.19$ \\
\hline $\mathrm{T}_{6}-$ & 13.93 & 193.94 & 10.77 & $1: 1.12$ \\
\hline $\mathrm{T}_{7}-$ & 14.87 & 217.47 & 12.08 & $1: 1.37$ \\
\hline $\mathrm{T}_{8}-$ & 12.80 & 129.59 & 7.20 & $1: 0.36$ \\
\hline $\mathrm{T}_{9-}$ & 13.60 & 184.41 & 10.24 & $1: 0.91$ \\
\hline S.Em $\mathbf{m}$ & 0.46 & 11.59 & 0.66 & - \\
\hline \hline CD $@ \mathbf{5 \%}$ & 1.39 & 34.75 & 1.98 & - \\
\hline
\end{tabular}


Table.3 Effect of integrated nutrient management (INM) on quality parameters of Strawberry cv. Sabrina

\begin{tabular}{|c|c|c|c|c|c|c|}
\hline Treatments & $\begin{array}{c}\text { TSS } \\
\left({ }^{0} \text { Brix }\right)\end{array}$ & $\begin{array}{c}\text { Total } \\
\text { sugars } \\
(\%)\end{array}$ & $\begin{array}{c}\text { Reducing } \\
\text { sugars }(\%)\end{array}$ & $\begin{array}{c}\text { None } \\
\text { reducing } \\
\text { sugars }(\%)\end{array}$ & $\begin{array}{c}\text { Titratable } \\
\text { acidity } \\
(\%)\end{array}$ & $\begin{array}{l}\text { TSS- } \\
\text { Acid } \\
\text { ratio }\end{array}$ \\
\hline $\mathrm{T}_{1}-$ & 8.67 & 5.75 & 4.15 & 1.60 & 0.69 & 12.50 \\
\hline $\mathrm{T}_{2}-$ & 9.63 & 5.87 & 4.60 & 1.27 & 0.65 & 14.89 \\
\hline$T_{3}-$ & 8.77 & 5.77 & 4.42 & 1.35 & 0.68 & 12.96 \\
\hline$\overline{T_{4-}}$ & 10.13 & 6.01 & 5.17 & 0.84 & 0.61 & $\overline{16.78}$ \\
\hline $\mathrm{T}_{5}-$ & 8.62 & 5.29 & 3.95 & $\overline{1.34}$ & 0.73 & 11.85 \\
\hline $\mathrm{T}_{6-}$ & 8.53 & 5.19 & 3.73 & 1.46 & 0.74 & 11.56 \\
\hline $\mathrm{T}_{7-}$ & 8.63 & 5.45 & 4.20 & 1.25 & $\overline{0.70}$ & 12.31 \\
\hline$T_{8}-$ & 8.40 & 4.87 & 3.54 & 1.33 & 0.74 & 11.35 \\
\hline $\mathrm{T}_{9^{-}}$ & 8.43 & 5.00 & 3.71 & 1.29 & 0.76 & 11.09 \\
\hline S.Em \pm & 0.26 & 0.14 & 0.13 & NS & 0.02 & 0.47 \\
\hline CD@ 5\% & 0.79 & 0.43 & 0.38 & NS & 0.05 & 1.41 \\
\hline
\end{tabular}

\section{Quality parameters}

The results on quality parameters except nonreducing sugars showed significant difference among the different treatments. The maximum total sugars $(6.01 \%)$, total soluble solids $\left(10.13^{\circ}\right.$ Brix $)$, reducing sugars $(5.17 \%)$ and TSS: Acid ratio (16.78) were recorded in the plants treated with $100 \% \mathrm{RDF}+\mathrm{VAM}$ $@ 10 \mathrm{~kg} / \mathrm{ha}+0.4 \%$ Boron spray $+0.5 \%$ $\mathrm{ZnSO}_{4}$ spray $\left(\mathrm{T}_{4}\right)$ (Table 3 ). The increased TSS and total sugars might be attributed to combined effect of biofertilizer and optimum nitrogen application received in the plants. Absorption of nitrogen may have exerted regulatory role as an important constituent of endogenous factors in affecting the quality of fruit in which carbohydrate is important and during ripening of fruits, the carbohydrate reserves of the roots and stem are drawn upon heavily by fruits which might have resulted into higher TSS and sugar contents in fruits (Antipchuk et al., 1982). Due to increase in TSS TSS: Acid ratio was found to be maximum. The current findings are in line with the findings of Ahmad and Mohammad (2012), Mohamed et al., (2011), Shehata et al., (2011), Pesakovic et al., (2013) and Rayees et al., (2015) in strawberry. The titratable acidity of the fruits was found to be significant among the treatments. The minimum titratable acidity $(0.61 \%)$ was recorded in the plants treated with $100 \% \mathrm{RDF}$ +VAM@10 kg/ha + 0.4\% Boron spray + $0.5 \% \mathrm{ZnSO}_{4}$ spray $\left(\mathrm{T}_{4}\right)$ which was on par with the application of $100 \%$ RDF + VAM @ $10 \mathrm{~kg} / \mathrm{ha}+0.4 \%$ Boron spray $(0.65 \%)$ $\left(\mathrm{T}_{2}\right)$. The reduction in titratable acidity may be attributed to conversion of organic acids and photosynthates into sugar during fruit ripening by applying biofertilizers (Esitken $e t$ al., 2010). The reduction in titratable acidity may also be due to utilization of acids as a substrate for respiration during the ripening and neutralization of organic acids due to potassium in tissues (Tisdale and Nelson, 1996). These findings are in close conformity with the results of Singh and Singh (2009), Khalid et al., (2013) and Umar et al., (2009) in strawberry.

\section{References}

Ahmad, D., and Mohammad, J., 2012, Impact 
of integrated organic nutrient combinations on fruit yields and quality of strawberry cv. Kurdistan in Iran. Journal of Ornamental and Horticultural Plants, 2(4): 251-256.

Anonymous, Indian Horticulture Database 2014. http://www.nhb.gov.in, P. 279.

Antipchuk, A. F., Tantsyarenko, E. V. and Mantselyaruk, R. M., 1982, Effect of bacteria on tomato yield and quality. Eknologiya Pr-va-I-Effectivnost Primeneniya-Bakterialnykh-Udobreni., 98-103.

Erturk, Y., Ercisli, S. and Cakmakci, R., 2012, Yield and growth response of strawberry to plant growth promoting rhizobacteria inoculation. J. Plant Nutr, 35: 817-826.

Esitken, A., Yildiz, H. E., Ercisli, S., Donmez, M. F., Turan, M. and Gunes, A., 2010, Effects of plant growth promoting bacteria (PGPB) on yield, growth and nutrient contents of organically grown strawberry. Sci. Hort., 124: 62-66.

Khalid, S., Qureshi, K. M., Hafiz, I. A., Khan, K. S. and Qureshi, U. S., 2013, Effect of organic amendments on vegetative growth, fruit yield and quality of strawberry. Pakistan J. Agric. Res., 26(2): 104-112.

Lieten, F., 1996, Effect of $\mathrm{Co}_{2}$ enrichment on greenhouse grown strawberry. Acta Hort., 439(2): 583-587.

Macit, I., Koc, A. Guler, S. and Deligoz, I. Yield, quality and nutritional status of organically and conventionally grown strawberry cultivars. Asian J. of Plant Scie., 6 (7): 1131-1136, 2007.

Martinsson, M., Kwast, A., Cieslinski, G. and Treder, W., 2009, Impact of production systems and fertilizer application on yield and quality of strawberries. Acta Hort., 708(5): 58-65.

Mehraj, H., Hussain, M.S., Parvin, S., M.Z.K. Roni. and Jamal Uddin, A. F. M., 2015,
Response of repeated foliar application of boron-zinc on strawberry. Int. J. Expt. Agric. 5(1): 21-24.

Mohamed, R. A., Hala, A., Abdelaal, and Abdelaziz, M. G., 2011, Effect of phosphorus, zinc and their interactions on vegetative growth characters, yield and fruit quality of strawberry. J. Hort. Sci. Orname. Plants, 3 (2): 106-114.

Mohamed, R. A., Hala, A., Abdelaal, and Abdelaziz, M. G., 2011, Effect of phosphorus, zinc and their interactions on vegetative growth characters, yield and fruit quality of strawberry. J. Hort. Sci. Orname. Plants, 3 (2): 106-114.

Patil, V. K., and Shinde, B. N., 2013, Studies on integrated nutrient management on growth and yield of banana cv. Ardhapuri (Musa AAA). J. Hort. Forestry., 5 (9): 130-138.

Pesakovic, M., Stajic, Z. K., Milenkovic, S. and Mitrovic, O., 2013, Biofertilizer affecting yield related characteristics of strawberry (Fragaria $x$ ananassa Duch.) and soil micro-organisms. Sci. Hort., 150: 238-243.

Ranganna, S., 1977, Manual of analysis of fruits and vegetables products. Tata Mcgrow Hill Pub. Co., Ltd., New Delhi. p. 255.

Rayees, A., Wani, Hakeem, S. A., Sabiya, B., Seerat, G., Mohammad, N. M. and Prasad, V. M., 2015, Impact of integrated nutrient management on growth, yield and quality of strawberry (Fragaria $\times$ ananassa Duch.) cultivation in India. Nature and Science, 13 (1): 39-44.

Rayees, A., Wani, Hakeem, S. A., Sabiya, B., Seerat, G., Mohammad, N. M. and Prasad, V. M., 2015, Impact of integrated nutrient management on growth, yield and quality of strawberry (Fragaria $\times$ ananassa Duch.) cultivation in India. Nature and Science, 13 (1): 39-44. 
Rubee L., Deepa H., Dwivedi, Ram, R. B., Meena, M. L. and Mukeshbabu, 2013, Impact of integrated nutrient management on growth parameters of strawberry cv. Chandler under subtropical conditions of Lucknow. Int. J. Agric. Boi. Res., 3 (3): 418-421.

Shehata, S. A., Gharib, A. A., Mohamed, M., Elmogy, Abdel Gawad, K. F. and Shalaby, E. A., 2011, Influence of compost, amino and humic acids on the growth, yield and chemical parameters of strawberries. Journal of Medicinal Plants Research, 5(11): 2304-2308.

Singh, A. K., Karma Beer and Pal, A.K., 2015, Effect of vermicompost and biofertilizers on Strawberry growth, flowering and yield. Annals of Plant and Soil Research 17 (2): 196-199.

Singh, A., and Singh, J. N., 2009, Effect of biofertilizers and bio regulators on growth, yield and nutrient status of strawberry cv. Sweet Charlie. Indian J. Hort., 66 (2): 220-224.

Tisdale, S. L., and Nelson, W. L., 1996, Soil fertility and fertilizers, Mc. Millan C London.

Umar, I., Wali, V. K., Kher, R. and Jamwal,
M., 2009, Effect of FYM, urea and Azotobacter on growth, yield and quality of strawberry cv. Chandler. Not. Bot. Hort. Agrobot. Cluj, 37 (1): 139143.

Umar, I., Wali, V. K., Ravikher and Sharma, A., 2008, Impact of integrated nutrient management on strawberry yield and soil nutrient status. Applied Biological Research 10: 22-25.

Wange, R. S., and Kzlogoz, 1998, Effect of biofertilizer on growth, yield and quality of strawberry. Ann. Agric. Sci. Mosthohor., 43 (2): 247-254.

Yadav, S. K., Khokhar, U. U. and Yadav, R. P., 2010, integrated nutrient management for strawberry cultivation. Indian J. Hort., 67 (4): 445-449.

Yadav, S. K., Khokhar, U. U. and Yadav, R. P., 2010, integrated nutrient management for strawberry cultivation. Indian J. Hort., 67 (4): 445-449.

Zargar, M. Y., Baba, Z. A. and Sofi, P. A., 2008, Effect of N, P and biofertilizers on yield and physiochemical attributes of strawberry (Fragaria $\times$ ananassa Duch.). Agro Thesis, 6 (1): 3-8.

\section{How to cite this article:}

Esmatullah Ahmadi, M. K. Honnabyraiah, Ashok S. Alur, J. Dinakara Adiga and Venkat Rao. 2017. Impact of Integrated Nutrient Management on Yield and Quality Parameters of Strawberry (Fragaria $\times$ ananassa Duch.) Cv. "Sabrina" under Polyhouse. Int.J.Curr.Microbiol.App.Sci. 6(9): 3481-3487. doi: https://doi.org/10.20546/ijcmas.2017.609.427 